\title{
EXPERIMENTS IN HUMAN VOLUNTEERS WITH ADENOVIRUS TYPE 8*†
}

\author{
BY \\ YUKIHIKO MITSUI, LAVELLE HANNA, RYOJI MINODA, \\ SHO OGATA, HIDEYO KURIHARA, RYOICHI OKAMURA, \\ AND MASAKO MIURA • \\ Department of Ophthalmology, Kumamoto University Medical School, Kumamoto, \\ Japan, and Department of Microbiology, University of California Medical School, \\ San Francisco, California, U.S.A.
}

IT is now well established that adenovirus type 8 is an aetiological agent of classical epidemic kerato-conjunctivitis (EKC) and perhaps the sole cause of that disease (Jawetz, Kimura, Hanna, Coleman, Thygeson, and Nicholas, 1955; Jawetz, Thygeson, Hanna, Nicholas, and Kimura, 1957). The virus has been isolated from EKC in different parts of the world (Mitsui and Jawetz, 1957; Hanna, Jawetz, Mitsui, Thygeson, Kimura, and Nicholas, 1957), and neutralizing antibodies to adenovirus type 8 develop regularly in the course of the illness (Jawetz, Thygeson, Hanna, Nicholas, and Kimura, 1956). The virus has caused clinical EKC when inoculated into the eyes of susceptible human volunteers, but has failed to produce clinical illness in the presence of type 8 serum antibody levels of 1:20 or greater (Mitsui, Hanabusa, Minoda, and Ogata, 1957). Vaccines of adenovirus type 3 give rise to specific neutralizing antibodies in man and protect against subsequent challenge with the homologous type (Heubner, Bell, Rowe, Ward, Suskind, Hartley, and Paffenbarger, 1955). The present study was undertaken to determine whether vaccination with adenovirus type 8 would induce specific antibodies and protect against subsequent challenge infection with either tissue-culture grown homologous virus, or infective material from typical cases of EKC.

\section{Materials and Methods}

Virus Strains.-Two strains of adenovirus type 8 were employed: "Ishi" isolated from a typical case of EKC in Japan, and "Trim", the prototype strain, isolated in 1954 in California. Viruses were grown in HeLa cell cultures in a maintenance medium consisting of mixture 199 with 10 per cent. chick serum, penicillin, and streptomycin. The same tissue culture system was also employed for the isolation of adenovirus type 8 from active cases of EKC.

In addition to virus strains cultivated in vitro, conjunctival scrapings from active cases of EKC of less than 5 days' duration served as a source of infective virus for challenge. Part of such EKC scrapings served as inoculum for vaccinated or unvaccinated volunteers while another part was inoculated into HeLa cell

* Received for publication October 24, 1958.

$\uparrow$ This study was supported by Arnold Reuben Fight for Sight Grant from the National Council to Combat Blindness, Inc., N.Y. and by Research Grant B-604 from the National Institutes of Health, Bethesda, Md. 
tissue cultures for virus isolation. Acute and convalescent serum specimens were obtained from such EKC-donors to establish the diagnosis of adenovirus type 8 infection, should virus isolation fail.

Preparation of Vaccine.-Adenovirus type 8 was grown in tissue culture at $37^{\circ} \mathrm{C}$. until cytopathogenic effects had progressed to ++++ readings. The tubes were then kept at $-8^{\circ} \mathrm{C}$. for one week. After thawing, the fluid was centrifuged twice at 3,000 r.p.m. for $20 \mathrm{~min}$. and each time the sediment was discarded. The undiluted supernate was tested for bacterial sterility by plating on blood agar and Sabouradud's agar and was then used as vaccine without inactivation. The concentration of viable virus in the supernate varied from lot to lot but usually was from 80 to $320 \mathrm{TCD} 50 / \mathrm{ml}$. when titrated in HeLa cell cultures.

Serological Tests.-Blood was drawn from all volunteers before and after the course of vaccination and intervals after the challenge infection. The serum was separated and stored until all specimens from a given individual could be tested simultaneously. Neutralization tests were performed according to a method described in detail elsewhere (Jawetz and others, 1956). Some of the tests were performed at Kumamoto, others in San Francisco, with good agreement in results. The results are stated as the reciprocal of the highest serum dilution neutralizing about 50 TCD50 of virus.

Vaccination of Volunteers.-After initial experiments indicated that the vaccine produced no ill effects (see results), each volunteer received on one, two, or three occasions at weekly intervals a total volume of $2 \mathrm{ml}$. vaccine. Of this amount, $0.1 \mathrm{ml}$. was injected intracutaneously and the rest subcutaneously 10 minutes later.

Challenge of Volunteers.-Volunteers were challenged for the first time from 4 to 9 weeks after the first vaccine injection. The first infectious inoculum was introduced by simple instillation into the conjunctival sac. At that time virus grown in tissue culture and containing $80-320 \mathrm{TCD} 50 / \mathrm{ml}$. was used as challenge inoculum. If the volunteer remained well for 2 weeks after the initial challenge by instillation, tissue culture virus was again administered by swabbing the scarified conjunctiva. If there was still no clinical evidence of infection, the patient was re-challenged with fresh conjunctival scrapings from an early active case of EKC (see Virus Strains above). Because suitable fresh cases of EKC were not regularly available as donors, the interval between second and third challenges was variable (see Table I). All challenged volunteers were carefully observed for signs of conjunctivitis or keratitis for at least 2 weeks. Serum specimens were obtained from all individuals, and re-isolation of virus was attempted in some cases exhibiting an ocular response to challenge.

\section{Results}

(1) Reactions to Injection of Viable Adenovirus Type 8 "Vaccine".-Before the beginning of volunteer studies, the vaccine was injected three times at weekly intervals into four of the present authors. Intradermal injection of $0.1 \mathrm{ml}$. resulted only in transient erythema of skin at the injection site, which subsided rapidly. This reaction bore no relation to the presence or absence of serum antibodies, or of immunity to adenovirus type 8 . The skin reaction 
appeared to have no allergic component either to the virus or to a constituent of the tissue culture medium. In patients recently recovered from EKC there was likewise no evidence that intradermal injection of adenovirus 8 can be employed as a test of past infection or of hypersensitivity or immunity. to this agent. The subcutaneous injection of $1.9 \mathrm{ml}$. vaccine gave rise to no local reaction, and in spite of careful observation no systemic manifestation of active infection could be detected.

(2) Antibody Response to Injection of Viable Adenovirus Type 8.-Serum antibody titres were measured in 42 persons after vaccine administration:

Group 1.-29 volunteers received three vaccinations at one-week intervals (Nos. 1-29). They showed a definite antibody response. In 22 of the 29 vaccinees the pre-vaccination titre of specific neutralizing antibody was 10 or less (Nos. 1-22); they showed a 4-fold or greater rise in antibody titre, with the post-vaccination titre reaching $40-160$. In seven of the 29 vaccinees the pre-vaccination antibody titre was 20 (Nos. 23-29); they showed a varying rise in antibody titre, reaching 40-160.

Group 2 and $2^{\prime}$.-Five volunteers received two vaccinations (Nos. 30-34). In four of them the pre-vaccination antibody titre was 10 or less (Nos. 30-33), and the post-vaccination titre reached 40-160. The fifth case (No. 34) had a pre-vaccination antibody titre of 20 and a post-vaccination titre of 40 .

Three other volunteers, with pre-vaccination antibody titres of less than 10 , also received two vaccinations but with a low-titre vaccine (Nos. 35-37). One of the three showed a definite antibody response (No. 35), but the others failed to show any antibody response (Nos. 36 and 37).

Group 3.-Five volunteers received one vaccination (Nos. 38-42). In all of them the pre-vaccination antibody titre was 10 or less. Two of them showed an antibody response, and the post-vaccination titre reached 20-40. The other three cases did not show a definite rise in antibody titre.

Thus a total of 42 volunteers were vaccinated, and 37 of them showed a significant antibody response (Tables I and II).

TABLE I

ANTIBODY RESPONSE TO VACCINATION

\begin{tabular}{l|c|c|c|c}
\hline \multirow{2}{*}{ TC-Titre of Vaccine } & \multirow{2}{*}{ No. of Vaccinations } & \multicolumn{3}{|c}{ Antibody Response } \\
\cline { 2 - 4 } & & Present & Absent & Total \\
\hline \multirow{2}{*}{$80-320$} & 3 & $29(22)^{*}$ & 0 & $29(22)$ \\
& 1 & $5(4)$ & 0 & $5(4)$ \\
& $2(2)$ & $3(3)$ & $5(5)$ \\
\hline 10 or Less & $1(1)$ & $2(2)$ & $3(3)$ \\
\hline Total & $37(29)$ & $5(5)$ & $42(34)$ \\
\hline
\end{tabular}

* Numbers in parenthesis indicate the number of persons in whom the vaccination antibody titre was 10 or less. 
TABLE II

RESULTS OF VACCINATION EXPERIMENTS

ANTIBODY RESPONSE AND PROTECTION AGAINST CHALLENGE-INDUCED ILLNESS

\begin{tabular}{|c|c|c|c|c|c|c|c|c|c|c|c|c|c|c|c|c|}
\hline \multirow{4}{*}{$\begin{array}{c}\text { Group } \\
\text { No. }\end{array}$} & \multirow{4}{*}{$\begin{array}{l}\text { No. of } \\
\text { Vaccina- } \\
\text { tions }\end{array}$} & \multirow{4}{*}{$\begin{array}{c}\text { Vaccine } \\
\text { TCD } 50 \\
\mathrm{ml} .\end{array}$} & \multicolumn{3}{|c|}{ Patient } & \multicolumn{5}{|c|}{$\begin{array}{l}\text { Neutralizing Antibody Titre } \\
\text { on Day after First Vaccination }\end{array}$} & \multicolumn{6}{|c|}{ Result of Challenges } \\
\hline & & & \multirow{3}{*}{ No. } & \multirow{3}{*}{ Age } & \multirow{3}{*}{ Sex } & \multirow{3}{*}{\multicolumn{2}{|c|}{ Day Titre }} & \multirow{3}{*}{\multicolumn{2}{|c|}{ Day Titre }} & \multirow{3}{*}{ Day Titre } & \multicolumn{4}{|c|}{ Tissue Culture Virus } & \multirow{2}{*}{\multicolumn{2}{|c|}{$\begin{array}{c}\text { Patient } \\
\text { Material } \\
\text { Swab } \\
\end{array}$}} \\
\hline & & & & & & & & & & & \multirow{2}{*}{\multicolumn{2}{|c|}{$\frac{\text { Instillation }}{\text { Day Result }}$}} & \multicolumn{2}{|c|}{ Swab } & & \\
\hline & & & & & & & & & & & & & Day $F$ & Result & Day $\mathbf{R}$ & esult \\
\hline 1 & $\begin{array}{l}\text { Three at } \\
\text { One-week } \\
\text { Intervals }\end{array}$ & $80-320$ & $\begin{array}{r}1 \\
2 \\
3 \\
4 \\
5 \\
6 \\
7 \\
8 \\
9 \\
10 \\
11 \\
12 \\
13 \\
14 \\
15 \\
16 \\
17 \\
18 \\
19 \\
20 \\
21 \\
22 \\
23 \\
24 \\
25 \\
26 \\
27 \\
28 \\
29\end{array}$ & $\begin{array}{r}64 \\
61 \\
23 \\
29 \\
35 \\
17 \\
45 \\
19 \\
49 \\
23 \\
28 \\
26 \\
4 \\
32 \\
18 \\
17 \\
51 \\
61 \\
29 \\
16 \\
30 \\
32 \\
35 \\
42 \\
30 \\
35 \\
19 \\
41 \\
37 \\
\end{array}$ & $\begin{array}{c}\mathbf{F} \\
\mathbf{F} \\
\mathbf{M} \\
\mathbf{F} \\
\mathbf{M} \\
\mathbf{M} \\
\mathbf{M} \\
\mathbf{F} \\
\mathbf{F} \\
\mathbf{F} \\
\mathbf{M} \\
\mathbf{F} \\
\mathbf{M} \\
\mathbf{F} \\
\mathbf{M} \\
\mathbf{F} \\
\mathbf{M} \\
\mathbf{F} \\
\mathbf{M} \\
\mathbf{F} \\
\mathbf{M} \\
\mathbf{F} \\
\mathbf{M} \\
\mathbf{F} \\
\mathbf{M} \\
\mathbf{M} \\
\mathbf{F} \\
\mathbf{F}\end{array}$ & $\begin{array}{l}0 \\
0 \\
0 \\
0 \\
0 \\
0 \\
0 \\
0 \\
0 \\
0 \\
0 \\
0 \\
0 \\
0 \\
0 \\
0 \\
0 \\
0 \\
0 \\
0 \\
0 \\
0 \\
0 \\
0 \\
0 \\
0 \\
0 \\
0 \\
0 \\
0\end{array}$ & $\begin{array}{r}<10 \\
10 \\
10 \\
<10 \\
10 \\
<10 \\
10 \\
<10 \\
<10 \\
10 \\
<10 \\
<10 \\
<10 \\
<10 \\
<10 \\
<10 \\
<10 \\
10 \\
<10 \\
<10 \\
<10 \\
10 \\
20 \\
20 \\
20 \\
20 \\
20 \\
20 \\
20\end{array}$ & $\begin{array}{l}41 \\
56 \\
52 \\
54 \\
35 \\
50 \\
45 \\
67 \\
51 \\
44 \\
42 \\
36 \\
37 \\
46 \\
31 \\
36 \\
44 \\
34 \\
38 \\
33 \\
65 \\
61 \\
36 \\
36 \\
53 \\
50 \\
56 \\
41 \\
\\
-\end{array}$ & $\begin{array}{r}40 \\
80 \\
>160 \\
80 \\
40 \\
160 \\
>160 \\
80 \\
160 \\
80 \\
80 \\
40 \\
40 \\
160 \\
40 \\
>160 \\
>160 \\
80 \\
80 \\
80 \\
40 \\
80 \\
80 \\
80 \\
160 \\
80 \\
80 \\
160 \\
\\
-\end{array}$ & 103 & $\begin{array}{l}42 \\
56 \\
52 \\
54 \\
54 \\
50 \\
50 \\
67 \\
51 \\
44 \\
42 \\
36 \\
37 \\
99 \\
31 \\
37 \\
44 \\
34 \\
38 \\
33 \\
65 \\
61 \\
41 \\
37 \\
64 \\
50 \\
56 \\
42 \\
47\end{array}$ & 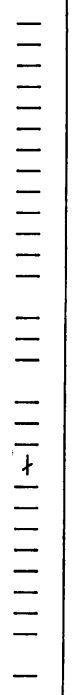 & $\begin{array}{r}74 \\
72 \\
68 \\
68 \\
97 \\
96 \\
86 \\
68 \\
57 \\
50 \\
51 \\
69 \\
113 \\
70 \\
58 \\
58 \\
0 \\
60 \\
60 \\
99 \\
77 \\
\end{array}$ & $\begin{array}{l}- \\
- \\
= \\
= \\
= \\
= \\
= \\
- \\
- \\
-\end{array}$ & $\begin{array}{c}119 \\
129 \\
252 \\
173 \\
199 \\
155 \\
247 \\
154 \\
156 \\
141 \\
181 \\
72 \\
130 \\
153 \\
87 \\
80 \\
321 \\
84 \\
91 \\
75 \\
90 \\
97 * \\
124 \\
208 \\
239 \\
141 \\
104 \\
258 \\
103\end{array}$ & 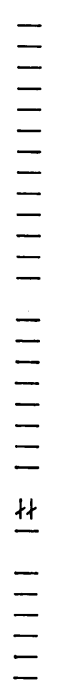 \\
\hline 2 & $\begin{array}{c}\text { Two at } \\
\text { One-week }\end{array}$ & $80-320$ & $\begin{array}{l}30 \\
31 \\
32 \\
33 \\
34 \\
\end{array}$ & \begin{tabular}{|l|}
23 \\
17 \\
52 \\
20 \\
22 \\
\end{tabular} & $\begin{array}{c}\mathbf{M} \\
\mathbf{F} \\
\mathbf{M} \\
\mathbf{M} \\
\mathbf{M}\end{array}$ & $\begin{array}{l}\mathbf{0} \\
0 \\
0 \\
0 \\
0\end{array}$ & $\begin{array}{r}<10 \\
<10 \\
<10 \\
10 \\
20\end{array}$ & $\begin{array}{l}32 \\
34 \\
30 \\
32 \\
33\end{array}$ & $\begin{array}{r}160 \\
40 \\
40 \\
160 \\
40\end{array}$ & $60 \quad 160$ & $\begin{array}{l}32 \\
34 \\
30 \\
32 \\
33\end{array}$ & $\bar{z}$ & $\begin{array}{l}45 \\
48 \\
45 \\
65 \\
46\end{array}$ & E & $\begin{array}{l}74 \\
64 \\
61 \\
76\end{array}$ & E \\
\hline $2^{\prime}$ & & $\begin{array}{l}10 \text { or } \\
\text { Less }\end{array}$ & $\begin{array}{l}35 \\
36 \\
37\end{array}$ & $\begin{array}{l}22 \\
27 \\
12\end{array}$ & $\begin{array}{l}\mathbf{F} \\
\mathbf{F} \\
\mathbf{M}\end{array}$ & $\begin{array}{l}0 \\
0 \\
0\end{array}$ & $\begin{array}{l}<10 \\
<10 \\
<10\end{array}$ & $\begin{array}{l}34 \\
31 \\
28\end{array}$ & $\begin{array}{l}80 \\
10 \\
10\end{array}$ & $\begin{array}{c}\S \\
187(144) 20 \\
68(28) 80\end{array}$ & $\begin{array}{l}48 \\
97 \\
37 \\
28\end{array}$ & $\bar{t}$ & & & & \\
\hline 3 & One & $80-320$ & $\begin{array}{l}38 \\
39 \\
40 \\
41 \\
42 \\
\end{array}$ & $\begin{array}{r}32 \\
30 \\
30 \\
8 \\
8\end{array}$ & $\begin{array}{c}\mathbf{M} \\
\mathbf{M} \\
\mathbf{F} \\
\mathbf{M} \\
\mathbf{F}\end{array}$ & $\begin{array}{l}0 \\
0 \\
0 \\
0 \\
0\end{array}$ & $\begin{array}{r}10 \\
10 \\
<10 \\
<10 \\
<10\end{array}$ & $\begin{array}{l}29 \\
31 \\
29 \\
30 \\
29\end{array}$ & $\begin{array}{l}40 \\
20 \\
10 \\
10 \\
10\end{array}$ & $\begin{array}{l}65(28) 40 \\
73(30) 80 \\
86(45) 40\end{array}$ & $\begin{array}{l}29 \\
31 \\
29 \\
30 \\
29\end{array}$ & $\bar{z}$ & $\begin{array}{l}43 \\
45\end{array}$ & - & 102 & - \\
\hline 4 & No & & $\begin{array}{l}43 \\
44 \\
45 \\
46 \\
47 \\
48 \\
49\end{array}$ & $\begin{array}{l}16 \\
61 \\
18 \\
20 \\
17 \\
27 \\
27\end{array}$ & $\begin{array}{c}\mathbf{F} \\
\mathbf{M} \\
\mathbf{M} \\
\mathbf{F} \\
\mathbf{F} \\
\mathbf{M} \\
\mathbf{F}\end{array}$ & $\begin{array}{l}0 \\
0 \\
0 \\
0 \\
0 \\
0 \\
0\end{array}$ & $\begin{array}{r}10 \\
<10 \\
<10 \\
<10 \\
10 \\
<10 \\
20\end{array}$ & $\begin{array}{l}40 \\
42 \\
46 \\
34 \\
43 \\
29 \\
44\end{array}$ & $\begin{array}{r}40 \\
80 \\
80 \\
80 \\
160 \\
40 \\
20\end{array}$ & & & & $\begin{array}{r}0 \\
0 \\
0 \\
0 \\
0 \\
18 \\
28\end{array}$ & $\begin{array}{c}\text { 奴 } \\
\text { 抽 } \\
\text { 好 } \\
= \\
-\end{array}$ & $\begin{array}{l}\mathbf{0} \\
\mathbf{0}\end{array}$ & 㛙 \\
\hline
\end{tabular}

* Challenged with adenovirus type 3 .

$-=$ Negative.

$t=$ Abortive or subacute conjunctivitis.

$\forall=$ Acute follicular conjunctivitis without keratitis.

$\nmid \nmid \downarrow=$ Acute follicular conjunctivitis with typical keratitis.

$\S$ Figures in brackets $=$ Number of days after onset of conjunctivitis. 
(3) Response of Volunteers to Challenge Infection.-Five vaccinees who had a pre-vaccination antibody titre of 10 or less, and who did not show a definite antibody response to vaccination, became infected by the first challenge. The incubation period varied from 6 to 13 days. Two of the five volunteers (Nos. 36 and 37) developed an acute follicular conjunctivitis which was followed by a typical subepithelial punctate keratitis. Two others developed a similar conjunctivitis without keratitis (Nos. 40 and 41). The fifth developed a subacute follicular conjunctivitis of shorter duration (No. 42). The five subjects exhibited a rise in specific neutralizing antibodies during their illnesses. In two of them re-isolation of the virus was tried after the onset of conjunctivitis and, from one of these, type 8 virus was recovered.

37 vaccinees who showed a definite antibody response were completely or partially resistant to challenge infection. 29 of them had pre-vaccination antibody titres of 10 or less, but had developed antibody in response to vaccination. 26 of the 29 did not show any reaction to repeated challenges. The remaining three developed an abortive, subacute conjunctivitis of short duration and no keratitis (Nos. 20, 33, and 35). Among the 37 vaccinees showing an antibody response, eight had pre-vaccination antibody titres of 20.

Challenges did 'not cause any illness in these individuals. One of the vaccinated volunteers (No. 22) who showed a satisfactory antibody response to adenovirus type 8 was challenged with scrapings containing adenovirus type 3 from a typical patient with pharyngo-conjunctival fever. This individual developed an acute follicular conjunctivitis with pre-auricular adenopathy, and a subsequent rise in antibody to adenovirus type 3 ; he had no keratitis or systemic symptoms.

Thus a definite illness was induced by a challenge in four of the five vaccinees who lacked antibody, and an abortive illness was induced in the fifth. These five persons developed neutralizing antibodies during the illness. No illness was induced by repeated challenges in 34 of the 37 vaccinees who possessed antibody; an abortive illness was induced in the remaining three (Table III, opposite). This resistance was type-specific.

Two non-vaccinated volunteers who were inoculated with patient material (Nos. 43 and 44) had antibody titres of 10 or less before inoculation. Both developed an acute follicular conjunctivitis after 7 and 9 days' incubation respectively, and in one of them a subepithelial punctate keratitis appeared. There was a definite rise in the specific neutralizing antibodies to adenovirus type 8 during the illness in both volunteers.

Earlier results of inoculating non-vaccinated volunteers with TC-virus have been reported (Mitsui and others, 1957), and are listed here for the sake of comparison. Five volunteers were inoculated with TC-virus on to the conjunctiva. Four of the five had pre-inoculation antibody titres of 10 or less. In all four, clinical EKC followed inoculation (Nos. 45-48), and in 
TABLE III

PROTECTION AGAINST CHALLENGE-INDUCED ILLNESS

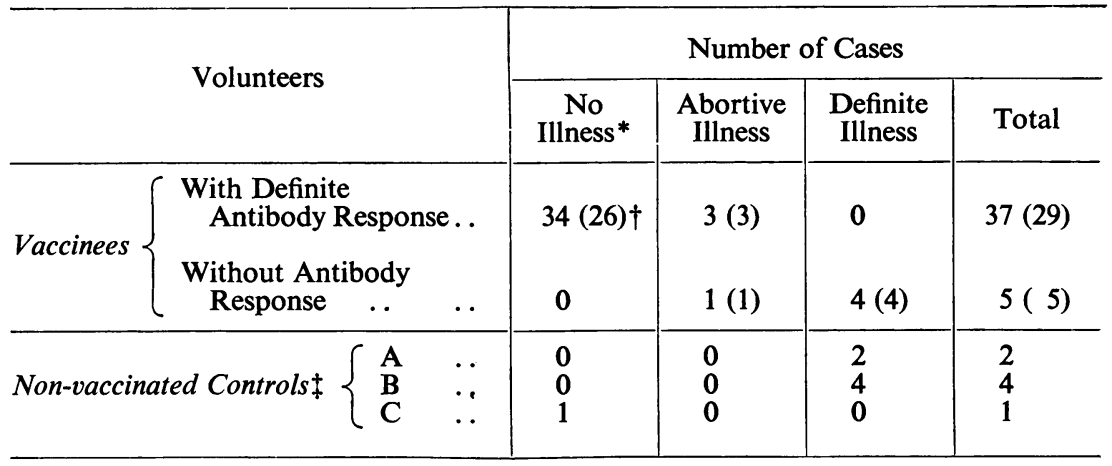

\footnotetext{
* No illness by repeated challenges.

$\dagger$ Numbers in parentheses indicate the numbers of cases which had a pre-vaccination. antibody titre of 10 or less.

$\ddagger$ A: Pre-inoculation antibody titre 10 or less, challenged with patient material.

B: Pre-inoculation antibody titre 10 or less, challenged with TC-virus.

C: Pre-inoculation antibody titre 20 , challenged with TC-virus.
}

three of the four typical keratitis developed. The fifth volunteer had a preinoculation antibody titre of 20 (No. 49). In this case repeated inoculations did not cause any lesion in the eye.

(4) Virus Isolation and Serological Results in Epidemic Kerato-Conjunctivitis (EKC) Patients serving as Donors for Challenge Inocula.-Virus isolation was attempted in eighteen patients with early EKC, and adenovirus type 8 was recovered from twelve of them. Scrapings from these EKC donors had served as challenge inoculum for 23 volunteers. No other viruses were recovered in HeLa cell cultures from these donors. Satisfactory paired sera available in thirteen of these EKC donors all showed a significant rise in specific neutralizing antibodies to adenovirus type 8 .

\section{Discussion}

The vaccine of adenovirus type 3 used by Huebner and others (1955) had a high infective titre of $300,000 \mathrm{TCD} 50 / \mathrm{ml}$. In type 8 virus the infective titre is relatively low, rarely exceeding $300 \mathrm{TCD} 50 / \mathrm{ml}$. Nevertheless, the virus content of our vaccine was sufficient to produce antibodies which protected against infection by the homologous virus. Another type 8 vaccine with an infective titre of $10 \mathrm{TCD} 50 / \mathrm{ml}$. or less was not satisfactory.

It is evident that three vaccinations one week apart cause a definite antibody response; the post-vaccination antibody titre reaches 40 to 160 . This titre is the same as that of convalescent serum of EKC patients. Two vaccinations at intervals of a week may also be adequate, but one vaccination is definitely' insufficient. It may be assumed that specific neutralizing 36 
antibody in a titre of 10 or less does not prevent the illness. Antibody levels of 20 or more prevent the illness in most instances.

Whereas the inoculation of humans with type 8 TC-virus has regularly caused clinical EKC in antibody-free volunteers, proper vaccination with type 8 virus regularly protected the volunteers. About 70-80 per cent. of the inoculations of volunteers with EKC patient material in Japan have shown a definite "take" (Aoki, 1941; Mitsui, 1948; Tanaka, 1957). A part of the negative results may have been due to an immunity, as demonstrated by Tanaka. Another part may have been due to a low concentration of infective virus in the inoculum. The largest concentration of virus in the eye occurs during the first few days of conjunctivitis. Subsequently the infective virus concentration diminished rapidly. Some of the failures of past transmission experiments may have been due to the use of late EKC cases as donors.

In the present experiments, antibody-free volunteers contracted EKC after the ocular inoculation of either tissue-culture-grown virus or fresh EKC scrapings containing adenovirus type 8 . Neither of these materials was able to produce disease in volunteers who had developed specific antibodies to adenovirus type 8 as a result of vaccination. This evidence lends additional weight to the belief that adenovirus type 8 is the aetiological agent of EKC. Our studies yielded no information concerning the possible need for trauma or coexisting herpetic infection for the development of EKC adenovirus type 8 infection, as suggested by others. Simple instillation of adenovirus type 8 (admittedly in the highest available infective concentration) sufficed as the sole demonstrable cause for the development of typical clinical EKC in our unprotected volunteers. It is becoming increasingly probable that adenovirus type 8 must be accepted as the principal, and perhaps the sole, aetiological agent in typical EKC.

Other types of adenoviruses have been isolated from similar conditions. Tanaka (1958) obtained an adenovirus type 7 and Ormsby, Fowle, and Doane (1957) obtained types 7 and 3 from donors with clinically similar illnesses. However, the inoculation studies of Tanaka and Watanabe (1958) and Sugiura (personal communication) clearly show that the clinical picture of illness resulting from adenovirus type 7 instilled into the eye differs markedly from typical EKC: the incubation period is short, and keratitis, if present at all, is not typical of EKC. The eye lesions of adenovirus type 3 infection were studied by our group in detail during recent outbreaks. They differ markedly from typical EKC, as detailed in a separate communication (Mitsui, Hanna, Hanabusa, Minoda, Ogata, Kurihara, Okamura, and Miura, 1959).

\section{Summary and Conclusions}

(1) The inoculation of adenovirus type 8, either grown in tissue culture or contained in fresh scrapings from typical cases of epidemic kerato-con- 
junctivitis (EKC), induced typical EKC in the human eye. The subcutaneous inoculation of viable adenovirus type 8 had no clinically observable effect whatever.

(2) Human volunteers vaccinated with two or three injections of viable adenovirus type 8 developed specific neutralizing antibodies to this virus and at the same time became resistant to ocular challenge inoculation with the agent. This immunity was strictly type-specific.

(3) The experiments reported here strongly support the impression that adenovirus type 8 is the principal aetiological agent causing epidemic keratoconjunctivitis in Japan.

The authors wish to thank Drs E. Jawetz and P. Thygeson of the University of California for aid in the preparation of this manuscript.

\section{REFERENCES}

AoKI, H. (1941). Acta Soc. Ophthal. (Japan), 45, 827.

Hanna, L., Jawetz, E., Mitsui, Y., Thygeson, P., Kimura, S. J., and Nicholas, A. (1957). Amer. J. Ophthal., 44, (Oct., Pt. 2) 66.

Huebner, R. J., Bell, J. A., Rowe, W. P., Ward, T. G., Suskind, A. G., Hartley, J. W., and Paffenbarger, R. S. (1955). J. Amer. med. Ass., 159, 986.

Jawetz, E., Kimura, S. J., Hanna, L., Colmman, V. R., Thygeson, P., and Nicholas, A. (1955). Amer. J. Ophthal., 40 (Nov., Pt. 2), 200.

, Thygeson, P., Hanna, L., Nicholas, A., and Kimura, S. J. (1956). Proc. Soc. exp. Biol. (N.Y.), 92, 91.

Mrtsui, Y. (1948). Acta Soc. Ophthal. (Japan), 52, 75-78.

, Hanabusa, J., Minoda, R., and Ogata, S. (1957). Amer.J. Ophthal., 43 (April, Pt. 2), 84. , Hanna, L., Hanabusa, J., Minoda, R., Ogata, S., Kurihara, H., Okamura, R., and Miura, M. (1959). A.M.A. Arch. Ophthal., 61, 891.

and JAWETZ, E. (1957). Amer. J. Ophthal., 43 (April, Pt. 2), 91.

Ormsby, H. L., Fowle, A. M. C., and Doane, F. (1957). Ibid., 43 (April, Pt. 2), 17.

Sugrura, S. Personal communication.

TanaKa, C. (1957). Amer. J. Ophthal., 43 (April, Pt. 2), 46. (1958). A.M.A. Arch. Ophthal., 59, 49. and Watanabe, H. (1958). Acta Soc. Ophthal. (Japan), 62, 1255. 